\title{
АКТУАЛЬНІ ПРОБЛЕМИ ІНДИВІДУАЛЬНОГО ЗДОРОВ'Я ПІДЛІТКІВ ТА ЗАСТОСУВАННЯ СУЧАСНИХ БІОТЕХНОЛОГІЙ ВИРОБНИЦТВА ФУНКЦІОНАЛЬНИХ ПРОДУКТІВ ХАРЧУВАННЯ 3 МЕТОЮ ЇХ ВИРІШЕННЯ
}

\author{
Непошивайленко Н. О., Корнієнко І. М.
}

\section{ВСТУП}

Забезпеченню розвитку та якісному існуванню суспільства сприяють здоров'я населення та тривалість його життя. Сучасна наука виділяє низку основних чинників, що впливають на особисте здоров'я людини. До них належать генетичні фактори, стан навколишнього середовища, медичне забезпечення, спосіб життя. Всі ці фактори в більшому чи меншому ступені відіграють важливу роль

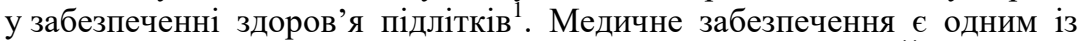
дієвих факторів зміцнення і збереження здоров'я підлітків. Його частка в зміцненні та збереженні ї здоров'я досить істотна і становить $10-15 \%$. Найбільший внесок у стан здоров'я, як свідчать дослідження вчених і життєвий досвід людей, привносить спосіб життя підлітків $50-55 \%{ }^{2}$. Основною складовою частиною способу життя є раціональне харчування. Раціональне харчування, забезпечуючи своєчасне і повне задоволення фізіологічних потреб організму в харчових речовинах i енергії, сприяє підвищенню працездатності, зміцнення здоров'я, підвищує стійкість до різного роду захворювань, забезпечує високу активність, бадьорість на довгі роки ${ }^{3}$. Особливої уваги потребують підлітки, харчові звички яких щорічно погіршуються"

Щороку в раціоні харчування підлітків суттєво падає відсоток поживно цінних продуктів, таких як фрукти, овочі, молочна та кисломолочна продукція, натомість зростає споживання вуглеводів, особливо швидких. Крім того, внаслідок використання сучасних технологій вирощування сільськогосподарської продукції та фермерства, оновлених технологій виробництва харчових продуктів із пролонгованим терміном реалізації, використовується велика кількість

${ }_{2}^{1}$ Грибан В.Г. Валеологія. Підручник. Київ : Центр учбової літератури, 2008. 214 с.

Разумов А.Н. Здоровье здорового человека (Основы восстановительной медицины) / А.Н. Разумов, В.А. Пономарев, В.А. Пискунов. Москва : Медицина, 1996. $414 \mathrm{c}$.

3 Лукьянова Е.М. Медицинские и педагогические аспекты проблемы сохранения здоровья детей. Международный медииинский журнал. 2003. Т. 9, № 3. С. 6-9.

4 Український інститут соціальних досліджень імені Олександра Яременка. URL: http://www.uisr.org.ua/hbsc 
небезпечних домішок (консервантів, антибіотиків, підсилювачів смаку тощо), які також негативно впливають на розвиток дитячого організму та дорослої людини загалом. Такі продукти харчування не володіють високою біологічною та харчовою цінністю, а навпаки, $є$ джерелом великої кількості небезпечних, токсичних речовин біологічного та хімічного походження. Зміна раціону харчування та хімікобіологічного складу харчових продуктів, за думкою лікарів, $є$ основною причиною розвитку важких хронічних захворювань за останні десятиріччя. Харчування здійснює вплив на розвиток та виникнення захворювань шлунково-кишкового тракту, печінки та жовчного міхура, ендокринних патологій, захворювань опорно-рухливого апарату. За даними ВО3, серед захворювань, які виникають внаслідок нездорового харчування, $61 \%$ становлять серцево-судинні захворювання, $32 \%$ - новоутворення, $5 \%$ - цукровий діабет II типу ${ }^{5}$.

Нагальним питанням сьогодення виступає поширення здорового способу життя та корисного харчування серед молоді та особливо серед підлітків, чий вік $\epsilon$ найбільш вразливим етапом розвитку людини, сприятливим до зниження рівня здоров'я та адаптації до розумових i фізичних навантажень.

Мета роботи полягає в комплексній оцінці складників індивідуального здоров'я підлітків та факторів, що на нього впливають із подальшою розробкою рекомендацій щодо використання сучасних біотехнологій отримання функціональних продуктів харчування на основі процесів молочнокислого зброджування субстратів та їх збагачення біологічно-активними речовинами.

Для досягнення поставленої мети необхідно вирішити такі задачі: провести соціологічне та фізичне дослідження серед підлітків різних вікових груп із метою суб'єктивного та об'єктивного оцінювання ступеню фізичної підготовки і стану їх здоров'я, якості і способу життя, наявності шкідливих звичок та ставлення до свого здоров'я; дослідити цінність харчування підлітків різних вікових груп; розробити математичні моделі залежності суб'єктивної й об'єктивної оцінки стану здоров'я підлітків та цінності їх харчування від віку; експериментально визначити роль молочнокислих бактерій та біологічно-активних речовин у технології отримання функціональних продуктів харчування для щоденного вживання їх підлітками; розробити удосконалені технології органічних продуктів харчування зі зниженою калорійністю, покращеними органолептичними та дієтичними властивостями.

5 Шафранський В.В. Європейська політика «Здоров'я-2020»: використання науково обгрунтованих стратегій для отримання позитивних результатів. Економіка і право охорони здоров'я. 2016 


\section{1. Комплексна оцінка індивідуального здоров'я підлітків}

За даними Державної статистичної служби України про стан здоров'я дітей $0-17$ років $^{6}$, за останні роки спостерігається зростання на $10 \%$ загальної кількості захворювань при майже незмінній кількості дитячого населення. При цьому показник захворюваності серед дітей збільшився для України загалом із 12900 випадків на 10000 населення у 2014 р. до 14200 випадків на 10000 населення у 2018 р.

За проведеним аналізом територіального розподілу захворюваності серед дітей 0-17 років, визначено найбільші показники $(5-6 \%$ від загальної кількості випадків на 1000 дитячого населення), характерні для Вінницької, Рівненської, Запорізької, Івано-Франківської та Житомирської областей, які не відрізняються складною екологічною ситуацією. Проте доволі рівномірний розподіл захворюваності серед дітей у межах 3-6\% свідчить про незначну залежність цього показника від екологічних факторів та підтверджує раніше обгрунтовані результати про залежність стану здоров'я дітей та підлітків від способу життя, раціону та цінності харчування ${ }^{7}$. Нозологічний розподіл захворюваності дітей України, наведений на рис. 1, свідчить, що більшість випадків захворювань серед дітей $0-17$ років пов'язано із хворобами органів дихання та становлять майже 60\%. Варто також вказати на вагому частину хвороб, що виникають внаслідок нездорового харчування, - це хвороби органів травлення, шкіри та підшкірної клітковини, кістково-м'язової системи та сполучної тканини, крові, кровотворних органів та системи кровообігу, ендокринної системи i розладу харчування, новоутворення, які становлять загалом понад $20 \%{ }^{8}$.

Методика дослідження. Суб'єктивне оцінювання способу життя проведено шляхом соціологічного опитування підлітків, а об'єктивне оцінювання фізичного стану здоров'я підлітків проведено за допомогою тесту Руф'є.

Для дослідження обрано учнів середніх загальноосвітніх шкіл м. Кам'янське Дніпропетровської області, які не мали хронічних захворювань, займались у звичайній групі $з$ фізичної культури та

6 Довідник «Показники здоров'я населення. Стан здоров'я дітей $0-17$ років включно (педіатрія)» 2014-2018 pp. - Державний заклад «Центр медичної статистики Міністерства охорони здоров'я України». URL: http://medstat.gov.ua/ukr/ MMXIV.html

Непошивайленко Н.О. Дослідження впливу техногенних факторів урбосистем на стан здоров'я та фізичний розвиток підлітків / Н.О. Непошивайленко, А.Г. Лупіна. Екологічні науки: науково-практичний журнал. Київ : ДЕА, 2019. № 1 (24). Т. 1. C. 26-33. DOI https://doi.org/10.32846/2306-9716-2019-1-24-1-4

8 Довідник «Показники здоров'я населення. Стан здоров'я дітей 0-17 років включно (педіатрія)» 2014-2018 рр. Державний заклад «Центр медичної статистики Міністерства охорони здоров'я України». URL: http://medstat.gov.ua/ukr/ MMXIV.html 
мали приблизно однакові умови проживання (територіально щодо джерел забруднення та споживання питної води, матеріального доходу та соціального статусу). Для оцінювання відібрано респонденти трьох вікових груп по 100 осіб у кожній групі дванадцятирічного, чотирнадцятирічного та шістнадцятирічного віку. Дослідження тривало впродовж двох років, тому у процесі праці 3 тією самою вибіркою респондентів отримано результати досліджень для таких вікових груп - тринадцятирічного, п’ятнадцятирічного та сімнадцятирічного віку.

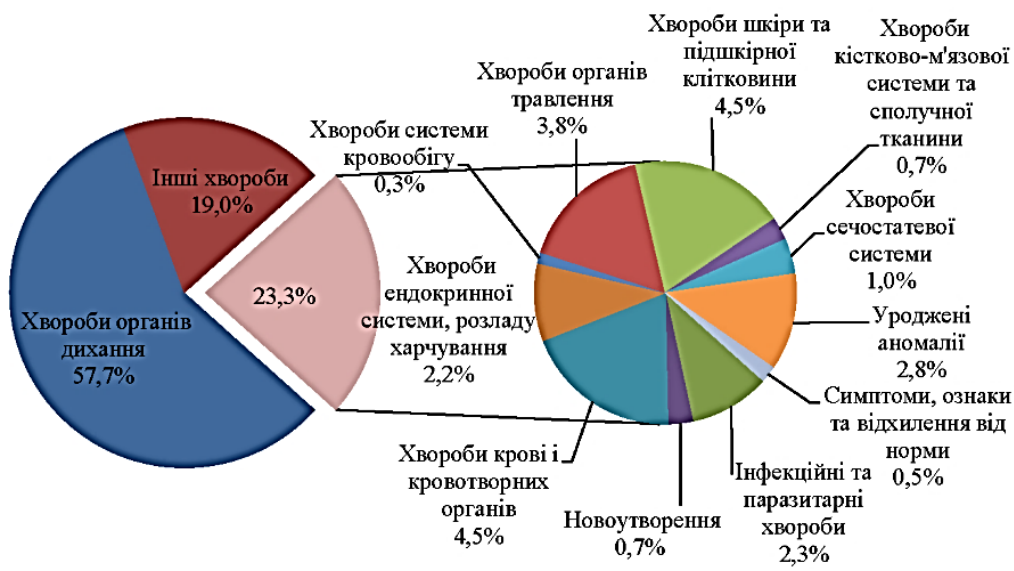

Рис. 1. Усереднений за роками (2014-2018 рр.) нозологічний розподіл захворюваності дітей на 1000 дитячого населення України

Соціологічне опитування проведено шляхом суб'єктивного самооцінювання респондентів ступеню фізичної підготовки, стану здоров'я, якості і способу життя, наявності шкідливих звичок та ставлення до свого здоров'я кожного респондента'. Тест складався 3 20 питань. Відповідна група питань уможливлює аналіз певної сторони особистості респондента (характер, рівень фізичної підготовки, турботу про своє здоров'я тощо), що дає змогу інтерпретувати відповіді опитуваних. Максимально за проходження тесту надається 40 балів, які розподіляються згідно з оцінюванням за таблицею 1.

\footnotetext{
${ }^{9}$ Непошивайленко Н.О. Дослідження впливу техногенних факторів урбосистем на стан здоров'я та фізичний розвиток підлітків / Н.О. Непошивайленко, А.Г. Лупіна. Екологічні науки: науково-практичний журнал. Київ : ДЕА, 2019. № 1 (24). T. 1. C. 26-33. DOI https://doi.org/10.32846/2306-9716-2019-1-24-1-4
} 
Таблиця 1

Оцінка соціологічного опитування

\begin{tabular}{|c|c|}
\hline Значення результату опитування & Оцінка \\
\hline $40-31$ балів & відмінно \\
\hline $30-21$ балів & добре \\
\hline $20-11$ & задовільно \\
\hline $10-0$ & незадовільно \\
\hline
\end{tabular}

Тест Руф'є - фізичне випробування, що оцінюється за допомогою таблиці 2 та за результатами якого можна судити про роботу серця під час фізичного навантаження ${ }^{10}$. Цей тест показує, який рівень навантаження може витримати людина без ризику для свого здоров'я, а 32009 р. став обов'язковим медичним дослідженням для школярів в Україні. На практиці цей тест показує, в якій групі з фізкультури має і зможе за станом здоров'я займатися дитина.

Таблиця 2

Оцінка тесту Руф'є

\begin{tabular}{|c|c|}
\hline Значення результату тесту Руф'с & Оцінка \\
\hline більше 15 & незадовільно \\
\hline $11-15$ & задовільно \\
\hline $6-10$ & посередньо \\
\hline $0-5$ & добре \\
\hline менше 0 & відмінна \\
\hline
\end{tabular}

Оцінювання енергетичної цінності харчування кожного 3 респондентів проведене шляхом визначення маси та складу харчових продуктів, що вони вживають. Респондентам запропоновано скласти меню їх добового харчування протягом тижня та узагальнений місячний раціон, який прийнято за усереднений харчовий раціон респондентів кожної вікової групи. За таблицями хімічного складу та енергетичної цінності харчових продуктів ${ }^{11}$ розраховано добове споживання білків, жирів, вуглеводів та енергетичної цінності харчування для кожного з респондентів та узагальнено для відповідної вікової групи. За нормативами цінності харчування для відповідних вікових груп, наведених у таблиці 3 , порівняно розрахункові результати 3 нормативними.

10 Функціональні проби в спортивній медицині (Методичні рекомендації) / Михалюк С.Л. Київ. 2005. 37 с.

11 Зубар Н.М. Основи фізіології та гігієни харчування: підручник. Київ : Центр учбової літератури, 2010. $336 \mathrm{c.}$ 


\section{Норми фізіологічних потреб дитячого населення України}

в основних харчових речовинах та енергії

\begin{tabular}{|c|c|c|c|c|}
\hline Вікова група & Енергія, Ккал & Білки, г & Жири, г & Вуглеводи, г \\
\hline $14-17$ років & $2700-2800$ & $90-100$ & $90-100$ & $375-400$ \\
\hline $11-13$ років & $2000-2500$ & $50-70$ & $50-70$ & $320-350$ \\
\hline
\end{tabular}

Результати досліджень.

Результати соціологічного опитування підлітків розподілено на групи за оцінкою, наведеною в таблиці 1, та представлено у вигляді діаграми, залежно від віку підлітків, на рисунку 2.

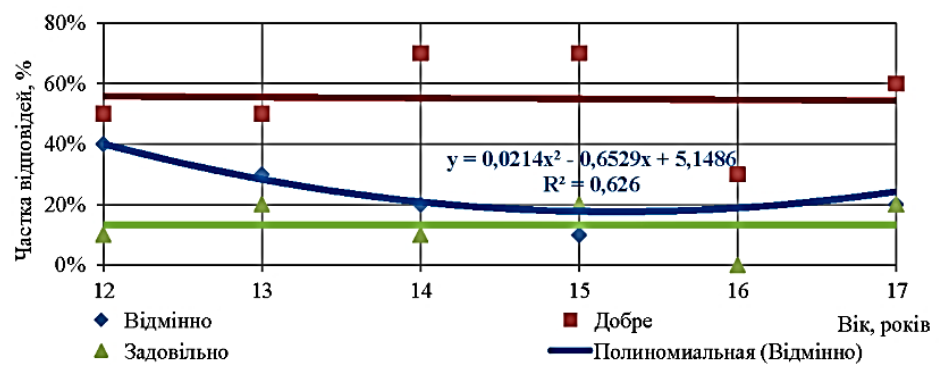

\section{Рис. 2. Узагальнені результати соціологічного опитування підлітків середніх загальноосвітніх шкіл м. Кам'янське Дніпропетровської області}

3 наведених діаграм видно, що респонденти усіх вікових груп отримали добру та задовільну оцінку майже в однаковому кількісному діапазоні $-55 \%$ та $15 \%$ відповідно. Отже, за цими результатами не виявлено вікової залежності суб'єктивної самооцінки підлітків про їх стан здоров'я, на відміну від відмінної оцінки соціологічного тесту. Найбільшу кількість респондентів високими балами оцінювання (оцінка «Відмінно») виявлено у підлітків 12-13-річного віку. Це свідчить про те, що їх батьки або самі підлітки в цьому віці більш піклуються про власний стан здоров'я, обізнані з цього питання, турбуються про власний організм, займаються спортом, а у більш старшому віці приділяють власному фізичному розвитку менше уваги, менше займаються спортом, піддаються впливу негативних соціологічних факторів чи навчальних навантажень, менше піклуються про власне індивідуальне здоров'я. Ці висновки також підтверджуються розрахованим вагомим значенням коефіцієнту кореляції $r=0,79$ та отриманим рівнянням поліномінального типу: 


$$
y=0,0214 x^{2}-0,6529 x+5,1486
$$

де $x$ - вік респондентів, роки; $y$ - кількісна самооцінка стан здоров'я респондентів, бали.

Загалом за узагальненими результатами соціологічного опитування, привалюють результати 3 оцінками «Відмінно» та «Добре», що свідчить про достатню високу обізнаність підлітків щодо турботи про стан свого здоров'я та впливу на нього різних соціально-екологічних факторів. Доведено, що діти з віком перестають займатися спортом та менш відповідально ставляться до власного індивідуального здоров'я.

Результати тесту Руф'є підлітків розподілено на групи згідно 3 оцінкою, наведеної в таблиці 2, та представлено у вигляді діаграми на рисунку 3.

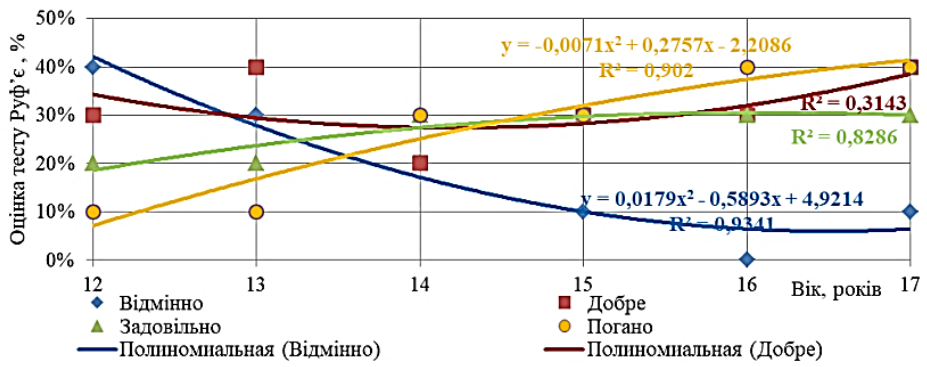

\section{Рис. 3. Узагальнені результати тесту Руф'є підлітків середніх загальноосвітніх шкіл м. Кам'янське Дніпропетровської області}

3 діаграм видно, що найкращий якісний стан здоров'я мають респонденти наймолодшої вікової групи (12-13 років) - оцінки «Відмінно» і «Добре» та становлять 30-40\% відповідно від загальної кількості результатів тесту Руф’є. Отримані результати для старшої та середньої вікових груп респондентів (14 років і старші) свідчать про дуже низький рівень їх активності й фізичної підготовки, при цьому цей показник має тенденцію до покращення, про що свідчать поліномінальні залежності другого порядку для кривих «Відмінно» та «Погано», наведені на рисунку 3.

Отриманий результат вікової залежності об'єктивного оцінювання фізичного стану здоров'я підлітків, проведеного за допомогою тесту Руф’є, підтверджується високими показниками коефіцієнтів детермінації, наведеними в таблиці 4, значимість яких перевірено за критерієм Фішеру при $\alpha=0,05$. Отже, сформована модель залежності тесту Руф’є від віку підлітків є адекватною, оскільки виконується умова $\mathrm{F}>\mathrm{F}_{\text {крит. }}$ 
Таблиця 4

Результати розрахунку параметрів лінійної регресії* залежності тесту Руф'є від віку підлітків м. Кам'янське Дніпропетровської області

\begin{tabular}{|c|c|c|c|c|}
\hline $\begin{array}{c}\text { Оцінка тесту } \\
\text { Руф'є }\end{array}$ & $\begin{array}{c}\text { Коефіцієнт } \\
\text { детермінації } \boldsymbol{r}^{2}\end{array}$ & $\begin{array}{c}\text { Фактичне } \\
\text { значення, F }\end{array}$ & $\begin{array}{c}\text { Стандартна } \\
\text { помилка } \\
\text { оцінки } \boldsymbol{y}\end{array}$ & $\begin{array}{c}\text { Рівняння } \\
\text { лінійної регресії }\end{array}$ \\
\hline Відмінно & 0,824 & 18,75 & 0,069 & $y=1,219 x-0,071$ \\
\hline Добре & 0,045 & $0,19<\mathrm{F}_{\text {кр }}$ & 0,082 & - \\
\hline Задовільно & 0,686 & 8,72 & 0,032 & $y=-0,065 x+0,023$ \\
\hline Погано & 0,881 & 29,79 & 0,052 & $y=-0,728 x+0,068$ \\
\hline
\end{tabular}

* при визначених ступенів свободи $\nu_{2}=4$ та рівні значущзості $\alpha=0,05$ критичне значення $F_{\kappa p}=7,71$

Розроблена математичну модель, наведена на рисунку 3 , що описується поліномом другого порядку за рівняннями (1) і (2), значимість яких підтверджується високими коефіцієнтами кореляції на

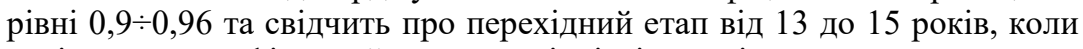
погіршується фізичний стан підлітків, згідно 3 отриманими результатами тесту Руф'є.

$$
\begin{aligned}
& y_{1}=0,0179 x^{2}-0,5893 x+4,9214, \\
& y_{2}=-0,0071 x^{2}+0,2757 x-2,2086,
\end{aligned}
$$

де $x$ - вік респондентів, роки; $y_{1}, y_{2}$ - кількісна оцінка стан здоров'я респондентів за тестом Руф'є, бали.

Отриманий узагальнений результат вимірювання тесту Руф'є свідчить про недостатній рівень фізичної підготовки підлітків, також можна припустити, що на зниження стану здоров'я підлітків із віком можуть впливати соціально-екологічні фактори, в тому числі режим та раціон їх харчування.

Узагальнені результати цінності добового харчового раціону підлітків залежно від віку наведено на рисунку 4.

За результатами досліджень виявлено перевищення добової максимальної норми вживання білків та усередненої енергетичної цінності харчового раціону підлітків усіх вікових груп, а для молодшої вікової категорії - майже двократне перевищення норми для білків. Із проведеного аналізу не виявлено нестачі добової норми вживання білку в жодної вікової групи респондентів, що свідчить про їх нормальний раціон харчування. Проте простежується тенденція до зниження вживання білкової їжі з віком, що негативно впливає на зростаючий організм підлітків у 16-17-річному віці, оскільки в цей час зріст не зупиняється, а активність, у тому числі розумова, збільшується. 

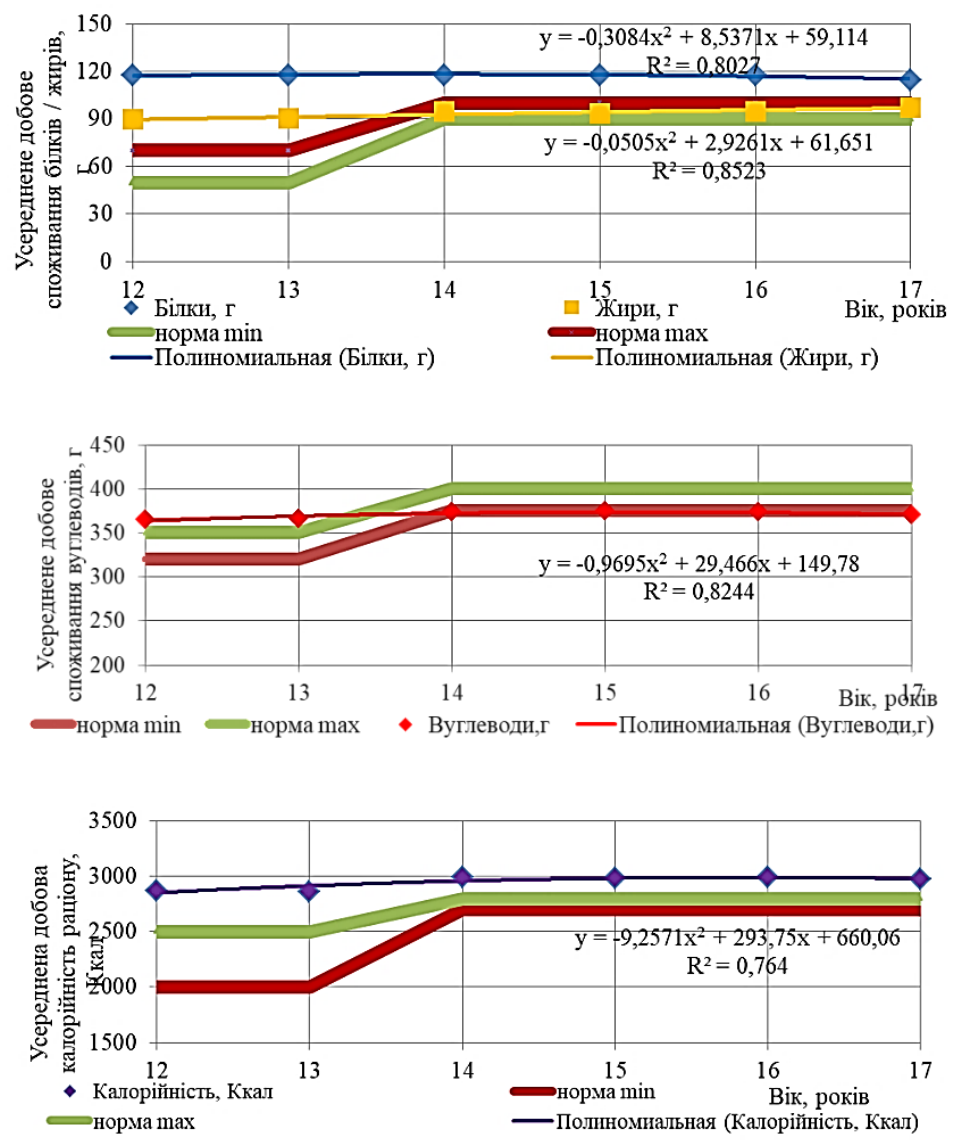

\section{Рис. 4. Узагальнені результати добового харчового раціону підлітків середніх загальноосвітніх шкіл м. Кам'янське Дніпропетровської області}

Встановлено, що жирів і вуглеводів підлітки старших вікових груп вживають із продуктами харчування в межах норми та лише в деяких випадках у респондентів спостерігається недоотримання жирів. Зовсім інша картина спостерігається у 12-13-річних підлітків, які майже удвічі перевищують норму вживання жирів та вуглеводів, що зумовлене споживанням 3 їжею в надзвичайно надмірній кількості таких продуктів, як жировмісні кондитерські вироби, жирні смажені страви, фаст-фуд та інші небезпечні продукти. Надмірне вживання вуглеводів 
цієї вікової групи може призвести до ожиріння та інших захворювань ендокринної системи.

Узагальнюючи складники їжі, яку вживають підлітки протягом доби, що характеризується іiі енергетичною цінністю, підсумована незначна надмірна кількість енергії для всіх вікових груп. Причому для більш дорослої вікової категорії респондентів перевищення від добової норми незначне та коливається в межах 5-10\%. Що ж стосується найменшої вікової категорії респондентів - перевищення від верхньої добової межи сягає 20\%. Це зумовлене надмірним вживанням їжі, що містить значну кількість білків, та особливо жирів та вуглеводів та негативно може вплинути на стан їх здоров'я. Але враховуючи, що виключно підлітки 12-13-річного віку ведуть активний спосіб життя (результати соціологічного опитування), багато займаються фізкультурою і спортом (результати тесту Руф'є), вживання їжі із значною кількістю енергії дає їм змогу залишатися бадьорими протягом усього дня та тільки за цих умов витрачати цю енергію.

Загалом встановлена значна кореляційна залежність цінності харчування від віку підлітків, що підтверджується високим значенням коефіцієнтів детермінації, які разом 3 отриманим рівнянням поліномінального типу наведені на рисунку 4.

\section{2. Сучасні біотехнології отримання функціональних продуктів харчування (на прикладі бездріжджового хліба, фруктової пастили та біологічно-активних йогуртів)}

Відповідно до представлених на рисунках 3-5 результатів досліджень, встановлено інтенсивне погіршення фізичного стану та загальної захворюваності підлітків внаслідок споживання неякісних продуктів харчування з перевищенням у раціоні значної частки простих вуглеводів, які призводять до збільшення калорійності раціону молоді. Для вирішення цього питання запропоновано технології виробництва функціональних продуктів харчування, найбільш спожитих молоддю, хліба, хлібобулочних виробів та кондитерських виробів (на прикладі фруктової пастили), а також біоактивних йогуртів, які рекомендовано до вживання в щоденному раціоні для покращення роботи шлунковокишкового тракту і джерела молочнокислих бактерій.

Розроблено рецептуру функціонального хліба на бездріжджовій заквасці з використанням корисних видів борошна, а саме: спельтового, гречаного, нутового, вівсяного, рисового та соєвого. Вказані види борошна зараховують до безглютенових, вони характеризуються підвищеним вмістом білку у порівнянні зі звичайним пшеничним та житнім борошном. Функціональний хліб наділений особливістю легко засвоюється організмом внаслідок ферментації борошняної складової частини симбіозом чистих культур молочнокислих бактерій 
родів -біфідо, -лакто та молочних стрептококів ${ }^{12}$. За рахунок симбіозу чистих культур молочнокислих бактерій термін зберігання цього хліба без жодних ознак псування пролонговано до 8 діб.

До складу закваски входить рекомендований симбіоз чистих культур молочнокислих бактерій, вода та борошна в різних комбінаціях. Готовий випечений хліб на основі бездріжджової закваски перевірено на вміст живих культур (дріжджів, молочнокислих бактерій, пліснявих грибів) шляхом висіву зразків хліба на елективні поживні середовища - середовище Сабуро, МПА з додаванням 2\% сахарози для ідентифікації дріжджів, біфідоагар, лактоагар ${ }^{13}$.

Особливістю цього бездріжджового хліба є те, що після випікання, потрапляючи до термостатних умов культивування на елективних поживних середовищах, молочнокислі бактерії є присутніми в усіх зразках хліба, виготовлених із різних видів борошна, на елективних середовищах - біфідо та лактоагар. У більшості зазначена присутність лактобактерій у порівнянні з біфідобактеріями, про що свідчать результати, наведені на рисунку 5.

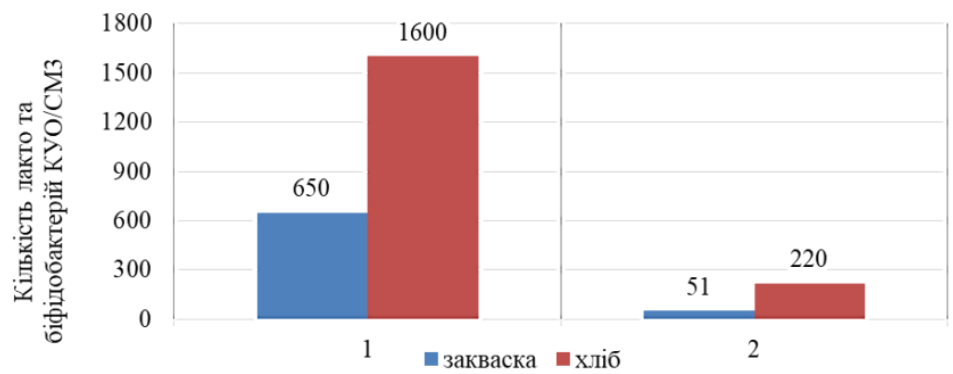

\section{Рис. 5. Результат визначення кількості лактобактерій (1) та біфідобактерій (2) в бездріжджовій заквасці та хлібі}

Отримані результати досліджень свідчать, що вирослі колонії на елективних поживних середовищах лакто та біфідоагар за морфологічними ознаками належать до молочнокислих бактерій. Навіть на чашках Петрі в досліджених зразках на МПА $з$ додаванням $2 \%$ сахарози методом забарвлення за Грамом виявлено за

${ }^{12}$ Comparative study of the content and profiles of macronutrients in spelt and wheat, a review / Escarnot E., Jacquemin J-M, Agneessens R., Paquot M. Biotechnology, Agronomy, Society and Environment. 2012. Vol. 16(2). P. 243-256.

Лабораторний практикум 3 технології хлібопекарського i макаронного виробництва / Дробот В.І., Арсеньєва Л.Ю., Білик О.А. Київ : Центр навчальної літератури, 2006. 341 с. 
морфологічними ознаками молочнокислі бактерії, які є конкуренто здатними стосовно дикорослих грибків та дріжджів.

За результатами досліджень встановлено, що в більшості знаходяться лактобактерії, кількість яких у заквасці та спеченому хлібі відповідає значенням 1600 та $220 \mathrm{KУO} / \mathrm{cm}^{3}$ відповідно, присутність біфідобактерій значно нижча порівняно 3 лактобактеріями і відповідають кількості 650 та $51 \mathrm{KУО} / \mathrm{cm}^{3}$ для закваски та хліба відповідно (рис. 5). Спечений на заквасці з молочнокислими бактеріями хліб відповідає усім вимогам за органолептичними ознаками (пористість, вологість, стислість м'якуша, зовнішній вигляд, смак). Результати досліджень свідчать про необхідність використання симбіозу чистих культур молочнокислих бактерій, які є антагоністами патогенних мікроорганізмів, беруть участь у пролонгації терміну зберігання хліба шляхом біосинтезу молочної кислоти як консерванту, покращення органолептичних показників, таких як пористість (шляхом інтенсивного процесу бродіння та виділення $\mathrm{CO}_{2}$ ) та вираженого ароматного смаку.

Результати досліджень свідчать, що в спеченому хлібі відбувається відновлення в термостатних умовах лакто- та біфідобактерій, кількість яких становить 220 та $51 \mathrm{KУО} / \mathrm{cm}^{3}$ відповідно. За результатами мікробіологічної оцінки закваски та спеченого хліба, зазначено відсутність бактерій групи кишкових паличок, патогенних грибів Aspergillus niger та мукорових грибів - Mycor mucedo, Bacillus subtilis збудника картопляної хвороби хліба, котрі були присутніми в деяких зразках пшеничного та житнього борошна. Цей факт говорить про ефективність використання симбіозу чистих культур молочнокислих бактерій у практиці отримання бездріжджової закваски задля забезпечення біобезпеки хліба та хлібобулочних виробів без використання консервантів та інших заходів забезпечення безпеки продуктів харчування.

Після аналізу характеру харчування підростаючим поколінням 3'ясовано, що вони надають перевагу солодощам. Тому запропоновано в щоденному раціоні замінити небезпечні солодощі, які призводять до дитячого діабету, на плодово-ягідну пастилу, збагачену нутрієнтами та консорціумом молочнокислих бактерій, які введено під час підсушування плодово-ягідної маси при температурі $37-40^{\circ} \mathrm{C}$. Такий температурний режим висушування плодово-ягідної маси призводить до збереження біологічної активності МКБ та нутрієнтів. Запропонована пастила є джерелом корисних волокон для нормалізації перетравлювання та субстратом для МКБ під час зберігання та реалізації готового продукту. У таблиці 5 наведено склад плодовоягідної пастили та іiї харчову цінність. 
Таблиця 5

Рецептура плодово-ягідної дієтичної пастили, додатково збагаченої нутріснтами

\begin{tabular}{|c|c|c|c|c|c|c|}
\hline Компоненти & $\begin{array}{c}\text { Кількість, } \\
\Gamma\end{array}$ & $\begin{array}{c}\text { Білки, } \\
\Gamma\end{array}$ & $\begin{array}{c}\text { Жири, } \\
\text { г }\end{array}$ & $\begin{array}{c}\text { Вуглеводи, } \\
\text { г }\end{array}$ & $\begin{array}{c}\text { Кал., } \\
\text { Ккал / } \\
100 \text { г }\end{array}$ & $\begin{array}{c}\text { Масова } \\
\text { частка, } \\
\%\end{array}$ \\
\hline $\begin{array}{l}\text { Волоський } \\
\text { горіх }\end{array}$ & 15 & 2,28 & 9,78 & 1,05 & 98,10 & 0,15 \\
\hline $\begin{array}{c}\text { Насіння } \\
\text { кунжуту }\end{array}$ & 5 & 0,97 & 2,44 & 0,61 & 28,25 & 0,05 \\
\hline Фруктоза & 5 & - & - & 4,99 & 19,95 & 0,05 \\
\hline Лактоза & 2,5 & - & - & 2,79 & 8,97 & 0,025 \\
\hline $\begin{array}{c}\text { Вітаміни: } \\
\text { А } \\
\text { E } \\
\text { C }\end{array}$ & $\begin{array}{l}0,005 \\
0,005 \\
0,005\end{array}$ & $\begin{array}{l}- \\
- \\
-\end{array}$ & $\begin{array}{l}- \\
- \\
-\end{array}$ & $\begin{array}{l}- \\
- \\
-\end{array}$ & $\begin{array}{l}- \\
- \\
-\end{array}$ & $\begin{array}{l}0,00005 \\
0,00005 \\
0,00005\end{array}$ \\
\hline $\begin{array}{c}\text { Яблунева } \\
\text { макуха }\end{array}$ & 15 & 0,06 & 0,06 & 1,47 & 7,05 & 0,15 \\
\hline $\begin{array}{c}\text { Фруктове } \\
\text { пюре }\end{array}$ & 57,5 & - & - & 8,35 & 34,80 & 0,575 \\
\hline Загалом & 100,515 & 3,31 & 12,28 & 19,26 & 197,12 & 100 \\
\hline
\end{tabular}

До складу запропонованої рецептури пастили введено симбіоз молочнокислих бактерій із метою ферментації готового продукту задля покращення його засвоювання організмом: Bifidobacterium lactis, Bifidobacterium longum, Bifidobacterium bifidum, Bifidobacterium breve, Bifidobacterium infantis, Lactobacillus casei, Lactobacillus rhamnosus, Lactobacillus acidophilus,Lactobacillus lactis, Lactobacillus bulgaricus, Propionibacterium freudenreichii, Streptococcus thermophilus. Методом мікробіологічних досліджень, шляхом висіву зразків плодово-ягідної пастили на елективне поживне середовища MRS, яке призначено для виділення МКБ, встановлено їх чисельність у готовому висушеному продукті, який наведено на рисунку 6.

3 огляду на результати досліджень встановлено, що найбільш придатним субстратом для збереження максимальної присутності МКБ є яблунево-гарбузова, яблунево-морквяна та яблунево-грушева пастила. Цей продукт є корисним, тому що володіє високою біологічною цінністю за рахунок живих МКБ та введених нутрієнтів, які необхідні для здорового та активного способу життя молоді. За органолептичною оцінкою, пастила відповідала усім встановленим нормам, а саме: смак, колір, запах, консистенція, поверхня, форма. 


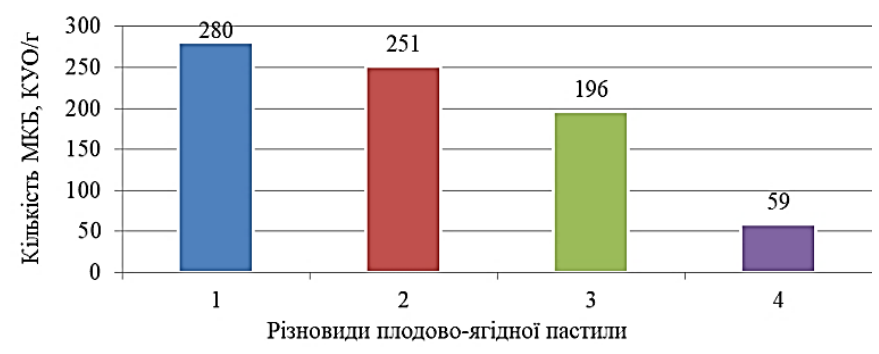

Рис. 6. Результат визначення кількості МКБ у дослідних зразках плодово-ягідної пастили, КУО/г: 1 - яблунево-гарбузова, 2 - яблунево-морквяна, 3 - яблунево-грушева, 4 - яблунево-сливова

Як джерела молочнокислих бактерій, повноцінного білку, вітамінів та амінокислот рекомендовано для щоденного вживання в раціоні молоді біоактивний йогурт із додаванням продуктів бджільництва - апі-продукти (мед, прополіс та пилок), які володіють лікувально-профілактичною дією щодо респіраторних захворювань, особливо природній антибіотик прополіс, $\epsilon$ джерелом вітамінів, ферментів, амінокислот, мікроi макроелементів. Перелічені апі-продукти корисні для зміцнення імунітету і боротьби з різними захворюваннями: при анемії, високому артеріальному тиску та інших серцево-судинних недугах, хворобах нервової системи, прополіс покращує кровообіг і зміцнює захисні сили організму. Крім цього, він володіє унікальною властивістю - підвищує ефективність деяких антибіотиків і сам діє як антибактеріальний i протизапальний препарат. Мед рекомендовано додавати до біойогуртів як натуральний підсолоджувач ${ }^{14}$. Одночасне застосування меду та прополісу надає продукту функціональній лікувально-профілактичній дії щодо шлунково-кишкових захворювань. Апі-продукти рекомендовано підростаючому поколінню, які не мають алергічний проявів на продукти бджільництва. Для групи підлітків, що мають алергічні реакції на апіпродукти, рекомендовано як біодобавку до йогуртів застосовувати сік алоє, ягоди Гольджі, різноманітні плодово-ягідні складники або фітокомпоненти.

Кисломолочний продукт одержували термостатним способом з ультрапастеризованого питного молока 3 масовою часткою жиру 3,2\%. Як закваску використовували препарат «Біфівіт» VIVO, до складу якого входять: Bifidobacterium lactis, Bifidobacterium longum, Bifidobacterium bifidum, Bifidobacterium breve, Bifidobacteriumin fantis, Lactobacillus bulgaricus, Lactobacillus acidophilus, Streptococcus thermophiles.

${ }^{14}$ Кузьмина К.А. Продукты пчеловодства и здоровье. Саратов : Саратовский университет. 1987 г. 151 с. 
Після закінчення процесу ферментації кисломолочний продукт перемішували i розливали в тару, куди вносили попередньо підготовлені наповнювачі. Як добавки використовували такі продукти бджільництва: мед квітковий, прополіс, пилок.

За результатами особистих досліджень були визначені оптимальні дозування наповнювачів за органолептичними показниками, а також за мікробіологічними дослідженнями: мед квітковий $-6 \%$, прополіс $-0,5 \%$, пилок $-5 \%$. Після внесення проводили гомогенізацію й настоювали продукт при температурі ферментації 40 хвилин. Одразу після приготування і в процесі зберігання були визначені мікробіологічні показники якості готового продукту порівняно біологічної активності молочнокислих бактерій. Дріжджі та плісняві гриби визначали шляхом посіву продукту на середовище Сабуро. БГКП визначали шляхом посіву продукту на диференціально-діагностичні середовища Ендо, Гіса. Молочнокислі мікроорганізми визначали шляхом посіву на середовище MRS. За результатами досліджень побудовано графічні залежності вмісту МКБ від використаних домішок.

У зразках біойогурту 3 медом та пилком на 7 добу зафіксовано присутність дріжджів, у кількості 25 та 42 КУО/мл відповідно. Плісняві гриби та БГКП не виявлено в жодному із зразків. Найбільш стабільні мікробіологічні показники спостерігаються у зразках продукту із прополісом. Це можна пояснити тим, що прополіс $\epsilon$ природним антисептиком, який певним чином впливає на ріст дріжджових клітин. Тому рекомендовано використовувати біойогурт із додаванням апіпродуктів зі строком зберігання не більше 3 діб.

Експериментами встановлено вплив внесених наповнювачів (апіпродуктів) на кількість молочнокислих мікроорганізмів. Дані наведено на рисунку 7.

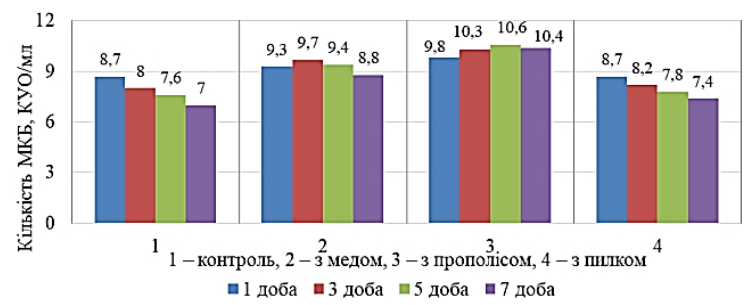

Рис. 7. Динаміка росту молочнокислих бактерій (МКБ) в біойогуртах 3 апі-продуктами, 7-10,6 $* 10^{8}$ КУО/мл: 1 - контрольна проба йогурту без додавання апі-продуктів, 2 - біойогурт $+6 \%$ меду, 3 - біойогурт + 0,5\% прополіс, біойогурт + $5 \%$ пилок

Мед та прополіс сприяли інтенсивному зростанню молочнокислих бактерій, усі досліджені зразки відповідають нормативним органолептичним показникам якості. Найбільш стабільні мікробіологічні й органолептичні властивості при зберіганні спостерігалися в зразку із 
прополісом. Це може бути пов'язане 3 його особливими мікробостатичними властивостями. За органолептичними показниками приготовлені біойогурти відповідали усім вимогам. Не рекомендовано збільшувати відсоток апі-продуктів внаслідок мікробіологічних змін та смакових уподобань. Особливо приємним на смак зазначено респондентами біойогурт із прополісом, тому що прополіс за хімічним складом містить коричну кислоту, ванілін та флаваноїди. Отримані результати досліджень рекомендовано використовувати для складання нових рецептур, збільшення асортименту функціональних продуктів із натуральними наповнювачами.

На жаль, з огляду на проведені експериментальні дослідження щодо раціону молоді та їх харчових уподобань встановлено суттєві відхилення від норм відповідно до калорійності продуктів, їх харчової цінності, які напряму залежать від перевищення в раціоні молоді вуглеводів та жирів. Для вирішення цього питання запропоновано ввести поступові зміни до раціону дітей та підлітків шляхом введення здорових, низькокалорійних продуктів функціонального призначення, збагачених нутріснтами та молочнокислими бактеріями, а саме: бездріжджовий хліб та хлібобулочні вироби на основі біоконцентрату молочнокислих бактерій; плодово-ягідну пастилу, збагачену вітамінами та симбіозом чистих культур молочнокислих бактерій із додаванням фруктози та лактози як підсолоджувачів та субстрату для розвитку і підтримки МКБ; біоактивний йогурт із додаванням апі-продуктів для налагодження роботи шлунково-кишкового тракту та профілактики вірусних та інфекційних захворювань.

\section{ВИСНОВКИ}

Суб'єктивне оцінювання способу життя підлітків середніх загальноосвітніх шкіл м. Кам'янське Дніпропетровської області у віковому діапазоні 12-17 років проведено шляхом соціологічного опитування, за результатами якого встановлено достатню обізнаність підлітків щодо власного здоров'я та здорового способу життя, проте доведено, що з віком підлітки перестають займатися спортом та менш відповідально ставляться до власного індивідуального здоров'я. Об'єктивне оцінювання індивідуального здоров'я за методикою тесту Руф'є показало, що найкращий якісний стан здоров'я мають респонденти наймолодшої вікової групи, результати найстаршої та середньої вікових груп свідчать про значно нижчий рівень їх фізичної активності й підготовки, при цьому цей показник має тенденцію до покращення.

Оцінювання усередненої цінності харчування підлітків та його складників, що потрапляють до організму підлітку, проаналізовано склад харчових продуктів, що вони вживають. Узагальнюючи складники їжі, підсумована незначна надмірна кількість енергії для всіх вікових груп, причому для більш дорослої вікової категорії респондентів перевищення від добової норми незначне та коливається в межах 5-10\%, а найменшої вікової категорії респондентів перевищення від верхньої добової межи сягає 20\%. Це зумовлене 
надмірним вживанням іжі, що містить значну кількість білків, та особливо жирів та вуглеводів.

Розроблено математичні моделі залежності суб'єктивної й об'єктивної оцінки стану здоров'я підлітків від віку, що описується поліномом другого порядку, a їх адекватність підтверджується високими показниками коефіцієнтів детермінації, значимість яких перевірено за критерієм Фішеру. Проведене моделювання свідчить про погіршення індивідуального стану здоров'я підлітків після 13-15-річного віку, у тому числі пов'язане з нераціональним харчуванням.

Встановлено, що одним із необхідних шляхів вирішення проблеми нераціонального харчуванням підлітків, зокрема, $\epsilon$ розробка покращених технологій виробництва функціональних продуктів харчування, а саме: бездріжджового хліба та хлібобулочних виробів із залученням корисних видів борошна - спельтове, нутове, вівсяне, гречане, соєве; плодово-ягідної пастили, збагаченої нутрієнтами та ферментованої симбіозом чистих культур молочнокислих бактерій; біойогуртів 3 апі-продуктами (прополісом).

Експериментами доведено збереження життєздатності МКБ у пастилі після висушування, кількість МКБ близько до 300 КУО/г. Плодово-ягідну пастилу збагачено вітамінами А, E, С, джерелом білку - волоським горіхами та кунжутним насінням, а як підсолоджувачі використано субстрати для зростання та підтримки росту МКБ - лактозу та фруктозу.

Рекомендовано рецептуру біоактивного йогурту збагаченого апіпродуктами - прополісом, пилком та медом. Доведено ефективність використання наповнювачів у зростанні кількості МКБ та покращенні органолептичних показників.

\section{АНОТАЦІЯ}

Проведено суб'єктивне та об'єктивне оцінювання фізичного стану та здоров'я підлітків, досліджено усереднений харчовий раціон підлітків різних вікових груп. Розроблено математичні моделі залежності суб'єктивної й об'єктивної оцінки стану здоров'я підлітків та цінності їх харчування від віку. Розроблено рекомендації щодо покращення раціону харчування підлітків: рекомендовано замінити висококалорійних хліб на функціональний бездріжджовий, виготовлений на основі спельтового, нутового, гречаного та вівсяного борошна 3 присутністю молочнокислих бактерій; рекомендовано замінити солодощі на плодово-ягідну пастилу, ферментовану симбіозом молочнокислих бактерій та збагачену нутрієнтами; рекомендовано функціональний біоактивний йогурт з апі-продуктами.

\section{ЛІТЕРАТУРА}

1. Грибан В.Г. Валеологія. Підручник. Київ : Центр учбової літератури, 2008. 214 с.

2. Разумов А.Н., Здоровье здорового человека (Основы восстановительной медицины) / А.Н. Разумов, В.А. Пономарев, В.А. Пискунов. Москва : Медицина, 1996. 414 с. 
3. Лукьянова Е. М. Медицинские и педагогические аспекты проблемы сохранения здоровья детей. Международный медииинский журнал. 2003. Т. 9, № 3. С. 6-9.

4. Український інститут соціальних досліджень імені Олександра Яременка. URL: http://www.uisr.org.ua/hbsc

5. Шафранський В.В. Свропейська політика «Здоров'я-2020»: використання науково обгрунтованих стратегій для отримання позитивних результатів. Економіка і право охорони здоров'я. 2016.

6. Довідник «Показники здоров'я населення. Стан здоров'я дітей 0-17 років включно (педіатрія)» 2014-2018 рр. Державний заклад «Центр медичної статистики Міністерства охорони здоров'я України». URL: http://medstat.gov.ua/ukr/MMXIV.html

7. Непошивайленко Н.О. Дослідження впливу техногенних факторів урбосистем на стан здоров'я та фізичний розвиток підлітків / Н.О. Непошивайленко, А.Г. Лупіна. Екологічні науки: науковопрактичний журнал. Київ : ДЕА, 2019. № 1 (24). Т. 1. С. 26-33. DOI https://doi.org/10.32846/2306-9716-2019-1-24-1-4

8. Функціональні проби в спортивній медицині (Методичні рекомендації) / Михалюк Є.Л. Київ. 2005. 37 с.

9. Зубар Н.М. Основи фізіології та гігієни харчування : Підручник. Київ : Центр учбової літератури, 2010. 336 с.

10. Comparative study of the content and profiles of macronutrients in spelt and wheat, a review / Escarnot E., Jacquemin J-M, Agneessens R., Paquot M. Biotechnology, Agronomy, Society and Environment. 2012. Vol. 16(2). P. 243-256.

11. Лабораторний практикум з технології хлібопекарського і макаронного виробництва / Дробот В.І., Арсеньєва Л.Ю., Білик О.А. Київ : Центр навчальної літератури, 2006. 341 с.

12. Кузьмина К.А. Продукты пчеловодства и здоровье. Саратов : Саратовский университет. 1987. 151 с.

\section{Information about authors:} Neposhyvailenko N. O.,

Candidate of Technical Sciences, Associate Professor, Dnipro State Technical University

2, Dniprobudivska str., Kamianske, Dnipropetrovsk region, 51900, Ukraine

Kornienko I. M., Candidate of Technical Sciences, Associate Professor, National Aviation University 1, Cosmonaut Komarov str., Kyiv, 03058, Ukraine 